\title{
Fiscaoeconomia
}

E-ISSN: 2564-7504

2022, Volume 6, Issue 1, 278-291

https://dergipark.org.tr/tr/pub/fsecon

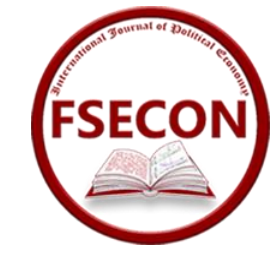

Research Article/Araştırma Makalesi

Submitted/Geliş: 21.10.2021

Accepted/Kabul: 13.01 .2022

Doi: $10.25295 /$ fsecon.1013123

\section{The Impact of COVID-19 on Industrial, Banking and Tourism Indexes}

\section{COVID-19'un Sanayi, Bankacılık ve Turizm Endekslerine Etkisi}

\section{Ayşe ERGIN ÜNAL ${ }^{1}$, Filiz YETiZ², Aynur SÜSAY ${ }^{3}$}

\begin{abstract}
The fight against COVID-19, which has become a global problem and still has an impact, still continues and a number of measures have been taken to mitigate the adverse economic impacts of the pandemic in Turkey. The measures taken affected each sector in the economy at different magnitudes. While results such as temporarily slowed-down production due to the first wave of the pandemic in certain production domains and decreased demand for manufactured goods have emerged, positive results also occurred due to the spread of remote online working as well as products such as food, cosmetics, hygiene and cleaning equipment, intense internet usage and the growth of manufacturing areas for smartphones, computers and so on, as well as increases in demand for those products. The extent to which sectors in the economy were affected throughout the pandemic has been an interesting research subject in the literature. Therefore, this study aims to examine the impacts of the COVID-19 pandemic on the industrial, banking, and tourism sectors within the Turkish economy. In the study, over the period between March 11, 2020 - April 22, 2021, the number of confirmed daily infected cases was selected as the independent variable, whereas the XU100, XUSIN, XBANK, and XTRSM indexes were selected as dependent variables. The Toda Yamamoto causality test was performed in the study in which the COVID-19 outbreak was examined within the context of specific indexes. The analysis results indicated that a unilateral causal relationship existed running from the number of confirmed daily infected cases to all indexes under examination.
\end{abstract}

Jel Codes: G12, G19, Z30.

Keywords: COVID-19, BIST 100, BIST Industrials, BIST Banks, BIST Tourism, Toda Yamamoto Causality Test.

1 Doç. Dr., Tarsus Üniversitesi Uygulamalı Bilimler Fakültesi, Finans ve Bankacılık Bölümü, ayseerginunal@tarsus.edu.tr, ORCID: 0000-0001-6551-8933

2 Doç. Dr., Akdeniz Üniversitesi, Uygulamalı Bilimler Fakültesi, Bankacılık ve Finans Bölümü, filiz.yetiz@gmail.com, ORCID: 0000-0001-5480-9268

3 Arş. Gör., Tarsus Üniversitesi Uygulamalı Bilimler Fakültesi, Finans ve Bankacılık Bölümü, aynursusay@gmail.com, ORCID: 0000-0003-0935-7375

Citation/Atıf: Ergin Ünal, A., Yetiz, F. \& Süsay, A. (2022). The Impact of COVID-19 on Industrial, Banking and Tourism Indexes. Fiscaoeconomia, 6(1), 278-291. Doi: 10.25295/fsecon.1028730. 
Ergin Ünal, A., Yetiz, F. \& Süsay, A. (2022). The Impact of COVID-19 on Industrial, Banking and Tourism Indexes. Fiscaoeconomia, 6(1), 279-292. Doi: 10.25295/fsecon.1028730.

\section{$\overline{0 ̈ z}$}

Küresel bir sorun haline gelen ve hala devam etmekte olan COVID-19 ile mücadele kapsamında Türkiye'de, özellikle olumsuz ekonomik etkileri azaltmak amaçlı birtakım önlemler alınmaktadır. Alınan önlemler ekonomideki her sektörü farklı büyüklüklerde etkilemiştir. COVID-19 sebebi ile belli üretim alanlarında salgının ilk dalgası nedeniyle üretim yavaşlarken bazı sanayi malları ve gıda ürünleri için talep artışı oluşmuş, akıllı telefonlar, bilgisayar ve benzeri gibi artan üretim alanlarının, kozmetik, hijyen ve temizlik ekipmanları, yoğun internet kullanımı ve uzaktan çevrimiçi çalışma gibi ürünlerin kullanımı daha da yaygınlaşmıştır. Ekonomideki sektörlerin pandemi boyunca ne ölçüde etkilendiği literatürde ilginç bir araştırma konusu olmuştur. Bu nedenle bu çalışma, COVID-19 pandemisinin Türkiye ekonomisi içindeki sanayi, bankacılık ve turizm sektörleri üzerindeki etkilerini incelemeyi amaçlamaktadır. Çalışmada 11 Mart 2020 - 22 Nisan 2021 tarihleri arasındaki dönemde doğrulanmış günlük enfekte vaka sayısı bağımsız değişken olarak seçilirken, XU100, XUSiN, XBANK ve XTRSM endeksleri bağımlı değişken olarak seçilmiştir. COVID-19 salgınının spesifik endeksler bağlamında incelendiği çalışmada Toda Yamamoto nedensellik testi yapılmış olup analiz sonuçları, doğrulanmış günlük enfekte vaka sayısından incelenen tüm endekslere kadar tek taraflı bir nedensellik ilişkisinin var olduğunu doğrulamaktadır.

Jel Kodları: G12, G19, Z30.

Anahtar Kelimeler: COVID-19, BIST 100, BIST Sanayi, Bist Turizm, Toda Yamamoto Nedensellik Testi.

\section{Introduction}

COVID-19 (coronavirus), which first emerged in Wuhan, China, and spread to all countries of the world, has reached the size of a pandemic in the process. While researching therapeutic medical practices for a certain period, many countries have taken a series of measures to at least reduce the spread, and this has led to different psychological, social, and economic consequences in the global sense. Although past tense expressions are being used, the process still continues and the pursuit of solutions to many foreseen/unpredictable problems in both the health sector (vaccination, scientific experiments, etc.) and the economic domain, is accelerating. Nonetheless, although many diseases have been experienced throughout the history of mankind, it is seen that the implemented policies tend to vary due to those experiences, the spread rate of the virus, and country differences. Although Yan et al. (2020) claimed that the markets would have reacted quite swiftly to the pandemic in the short-run and that the losses would have turned into gains in the long-run, it is thought to be quite early to make such judgment. Therefore, countries have to employ different methods apart from the experience they had faced in the presence of other pandemics in history. Curfews, full/partial lockdowns, closure of workplaces, social isolation concepts, and practices have entered the literature along with the virus, and they have led to various sociological and economic consequences. Upon examining the general macroeconomic impacts of COVID-19, it is seen that health expenditures covering expenses such as the treatment process of patients and rehabilitation, as well as appropriations made to companies that have sales and cost problems due to the pandemic, lead to an unplanned increase in expenditures in the country's economy. In other words, many countries' economies are being tested by familiar macroeconomic problems such as inflation and unemployment, while they are in pursuit of 
Ergin Ünal, A., Yetiz, F. \& Süsay, A. (2022). The Impact of COVID-19 on Industrial, Banking and Tourism Indexes. Fiscaoeconomia, 6(1), 279-292. Doi: 10.25295/fsecon.1028730.

solutions to newly emerging problems. In this process, many companies within the industrial and services sector have been exposed to different costs and practices according to the sector and try different ways in order not to decrease their firm values.

Studies conducted on the rapid spread of the COVID-19 pandemic attract attention to the fact that the disease has a strong contagious impact on financial markets around the world, and it is quite troublesome to predict the magnitude of its social and economic consequences. Some of the continuous debates regarding the nature of the ongoing crisis especially relate the economic consequences of the pandemic to the 2008 global financial crisis, while some other debates attribute it to terrorist attacks, natural disasters, and past epidemics (Yarovaya et al., 2020: 1). Some studies (Yarovaya et al. (2020), Morales et al. (2020), J Amankwah-Amoah (2021), CC Ngwakwe (2020), and Antipva (2020)) attributed economic and financial events depending on the extent of the pandemic to the black swan scenario. This concept is used for rare events that are quite likely to affect the financial and economic sectors deeply and are difficult to predict.

Among the studies conducted on the impacts of COVID-19 on global financial markets, Morales et al. (2020) stated that while the markets did not react to the volatility levels exhibited by the Shanghai Stock Exchange, in the first case of Italy, it was perceived as a global threat by the actors in the markets and it triggered the fears of the European stock markets. Following this stage, global uncertainty was thought to have reached a global financial dimension with global markets in a 'free fall' until the end of February 2020 due to the lack of active and coordinated responses by politicians and monetary authorities. Likewise, this situation makes it easier for both politicians and financial actors to associate the pandemic with the black swan event. Another event that supported this view was the sharp decline $(7 \%)$ observed in the US stock markets and the interruption of transactions for 15 minutes due to the circuit breaker mechanism that was put into practice. Again, in the same period, the world's major stock market indexes lost almost $30 \%$ in value, and these losses were such as S\&P 500 (31\%), Dow Jones (34\%), FTSE 100 (34\%), DAX (35\%), NIKKEI 225 (27\%), Shanghai (14\%), and BIST 100 (29\%), respectively (Senol, 2020: 76).

It is obvious that the uncertainty and increasing risk occurring in global markets during the COVID-19 pandemic process have also been experienced in Turkey, and certain measures were tried to be taken in order to avoid permanent macroeconomic and financial problems in the early phases. In Turkey, where the first case was seen on March 10, 2020, the first economic measure package was announced on March 18, and in this regard, some decisions were taken on tax liabilities of $€ 100$ billion, loans, short-term working allowance, and assistance to families in need. The CBRT, on the other hand, firstly, cut the policy rate within the scope of monetary policy, decreased the one-week interest rate from $10.75 \%$ to $9.75 \%$, and implemented many policy decisions besides this cut. The new liquidity opportunities provided to banks include reducing the monthly maximum contractual interest rate from $1.4 \%$ to $1.25 \%$ for credit card transactions, extending the maturity up to 90 days for rediscount loan repayments due between March 18 - June 30, and TL denominated foreign currency interest rates discounts are just a few of them.

With the declaration of a pandemic by the World Health Organization, various restrictions have been made in travel and tourism activities in order to prevent the spread of the 
Ergin Ünal, A., Yetiz, F. \& Süsay, A. (2022). The Impact of COVID-19 on Industrial, Banking and Tourism Indexes. Fiscaoeconomia, 6(1), 279-292. Doi: 10.25295/fsecon.1028730.

pandemic, and almost all international flights have been suspended. The United Nations World Tourism Organization (UNWTO) has made an assessment that COVID-19 has damaged the tourism sector 8 times as much as the global crisis. In July 2020, international tourist movements decreased by $81 \%$ compared to the same period of the previous year, and by $79 \%$ in August (TÜRSAB, 2020: 6). UNWTO calls for strong coordination of travel protocols among countries to ensure a safe resumption of tourism and to avoid another year of major losses in the sector. With the occurrence of the infected cases in Turkey, in parallel with the world, a series of measures have been taken to restrict the mobility of the sector, such as capacity limitation, social distance rules, travel restrictions, closure of hotels. By the end of the successful fight against the pandemic, the controlled normalization process was initiated in Turkey, and tourism activities began in the 2020 season under the necessary precautions.

The impacts of COVID-19 on BIST 100, BIST Industrial, BIST Banking, and BIST Tourism indexes are examined within the scope of causality in this study which consists of three parts. Again, the study, based on other studies that predict the economic consequences of COVID-19 or evaluate the impacts of other pandemics, considers the economic and social impact of the pandemic in financially selected sectors. It is thought that dealing with the possible impacts of COVID-19 on financial markets and institutions directly or indirectly within the scope of causality would contribute to the implementation of sectoral policies, especially in the future. In this context, following the introduction, the economic dimension of the pandemic, whose history does not go quite way back, is briefly summarized based on various works of literature and by segmentation. Consequently, it is seen that different aspects of the industrial, banking, and tourism sectors in the Turkish economy have been affected by the COVID-19 process, and policies and measures to reduce the adverse impacts of the pandemic continue to be taken in Turkey. It is thought that the study would contribute to the literature as it provides a sectoral perspective on the pandemic and presents the changes in the stock market.

\section{Literature Review}

\section{1. Literature Review Regarding the Macroeconomic and Sectoral Impacts of COVID-19}

Studies investigating the macroeconomic and sectoral impacts of COVID-19 are rapidly multiplying in the literature. Karabağ (2020), which called for research in many fields such as economics, business, and technology related to the pandemic, discussed the possible impacts of the pandemic in various fields such as global, national, commercial, economic, and social in the short- and long-run. Baker, Bloom et al. (2020) evaluated the macroeconomic impacts of COVID-19 on the US economy. Upon evaluating those impacts, indicators of stock market volatility, economic uncertainty, and labor markets were used. As a result of the findings, it was determined that the US real GDP (Gross Domestic Product) might have experienced a contraction of approximately $11 \%$ on an annual basis as of the last quarter of 2020 , and half of that contraction in output might have been due to uncertainties based on COVID-19. Cinel (2020) examined the economic impacts of COVID-19 on both industries and countries and mentioned the necessary precautions to be taken and policies to be implemented. Dündar (2020) investigated the macroeconomic impacts of global pandemics. In the study, upon comparing to previous global pandemics, the global economic impacts of COVID-19, especially in China, were examined and some policy recommendations regarding the pandemic were included. 
Ergin Ünal, A., Yetiz, F. \& Süsay, A. (2022). The Impact of COVID-19 on Industrial, Banking and Tourism Indexes. Fiscaoeconomia, 6(1), 279-292. Doi: 10.25295/fsecon.1028730.

Adıgüzel (2020), in which the impacts of COVID-19 in Turkey were investigated macroeconomically, asserted that COVID-19 negatively affected employment, production, exports, current account deficit, personal and business incomes, budget deficit, and central government total debt burden in the country's economy, and caused the recession. Soylu (2020), in which the impact of COVID-19 on macroeconomic indicators was examined, mentioned the changes in sectoral confidence indexes, labor market, foreign trade statistics, industrial production index, tourism revenues in the Turkish economy throughout the pandemic process. It was stated that financial expansion programs were implemented to support households and companies in the presence of the pandemic, wage subsidies were given, and financial aid and emergency financial supports were applied. It was also stated that efforts were made to ensure financial stability with a liquidity expansion and low-interest-rate policy. In summary, the changes in the macroeconomic indicators in the Turkish economy were examined in the study.

Examining the impacts of the COVID-19 pandemic in terms of sectors, Kılıç (2020) examined the impacts of coronavirus on Borsa İstanbul sector returns using the event study method. Upon evaluating the results of the analysis, it was determined that the highest negative returns on a sector basis were in the tourism and textile sectors, whereas the positive returns were in the trade sector. Koyuncu and Meçik (2020), investigating the impacts of the COVID19 pandemic on the economic sectors in Turkey, examined the impact of pandemic shocks employing the VAR analysis method. In the analysis, the construction sector cost index, industrial production index, retail trade and service sector, manufacturing industry capacity utilization rate, export and import sector index, employment rate variables were used, taking into account the monthly data obtained over the period between 2015:01- 2020:05. In the results of the study, it was observed that the retail trade and service sector, industry, and manufacturing sectors were the fastest-reacting sectors toward shocks, whereas construction was the slowest-reacting sector toward the shocks. In their study, Julius, Nuugulu, and Julius (2020) concluded that the impact of the pandemic on the Namibian economy was negative in the tourism sector, construction, mining, and quarrying, manufacturing sectors, whereas positive in the agriculture, forestry, and fishing sectors and technology. Ludvigson et al. (2020) investigated the impact of COVID-19 employing the VAR method, taking into account the quarterly data obtained over the period 1980-2019. The results of the research study concluded that a shock that could last from 2 months to 1 year might have encountered a contraction of $12.75 \%$ in industries and $17 \%$ in service sector employment. Ramelli and Wagner (2020), in which the impacts of COVID-19 were investigated, stated that the negative impact was high, especially in the finance, energy, insurance, and transportation sectors in China. Along with the pandemic, measures such as the closure of shopping centers, restaurants, curfews, and the transition to distance education also affected the e-commerce sector. Kayakuş and Çevik (2020) examined the changes in the number of visitors to ecommerce sites in Turkey during the COVID-19 process and determined that the statistical data in the pandemic process directly affected online shopping. 
Ergin Ünal, A., Yetiz, F. \& Süsay, A. (2022). The Impact of COVID-19 on Industrial, Banking and Tourism Indexes. Fiscaoeconomia, 6(1), 279-292. Doi: 10.25295/fsecon.1028730.

\section{2. Literature Review Regarding the Impacts of COVID-19 on the Banking and Finance Sector}

Upon examining the literature on the banking sector, which is one of the fastest-adapting sectors to the COVID-19 epidemic process, Arabacı and Yücel (2020) evaluated the impact of the COVID-19 pandemic on the Turkish banking sector. It was stated that a series of policies began to be implemented, such as restructuring loans and debts, offering low-interest loan options, providing liquidity support to the market, and changes in policy rates during the fight against the pandemic. Beybur and Çetinkaya (2020) analyzed the data regarding the usage of digital products and services in the banking sector and evaluated the impact of the pandemic on the usage of digital banking products and services. The annual data obtained over the period between 2019:09 and 2020:09 was utilized in the analysis. According to the results obtained from the study, it was stated that the banking sector actively used digital channels in the process, there was an increase in the number of digital banking customers, and most of the customers used digital banking channels merely out of necessity.

Bekçi, Köse, and Aksoy (2020) intended to gather information about the asset quality of selected banks for the ratio that indicates the asset quality of the banks during the pandemic process (total loans/total deposits ratio). For the analysis, the quarterly data of nine different banks obtained over the period 2019:01-2020:02 were utilized, and the GM $(1,1)$ estimation model was chosen as the method. In the obtained analysis results, it was estimated that there would have been a decrease in the ratios indicating the asset quality of six banks, and an increasing trend would have been experienced in the ratios indicating the asset quality of the other three banks. Matos et al. (2021) examined the banking system by proposing a risk-based empirical analysis during the pandemic process. In the study, the data of daily returns of G7 banking sector indexes over the period between January 01, 2015 - December 31, 2019 (prior to the pandemic) and January 01, 2020 - October 16, 2020 (during the pandemic) were utilized and the Granger causality test was performed. The VAR analysis results revealed that a relationship existed between the $\mathrm{G} 7$ financial indexes and the banking systems, taking into account 21 different possible binary combinations. Greenwald, Krainer, and Paul (2020) detected that banks imposed restrictions on term loans due to the COVID-19 pandemic process during which credit limits were reduced by banks. Wojcik and Ioannou (2020) investigated the impacts of the worldwide pandemic on the financial sector. In the study, it was stated that retail banking would have been the leading sector of the financial system.

Sansa (2020) investigated the impact of the pandemic process in the USA and China on the financial markets over the period between March 1 - March 25, 2020. The obtained results asserted that a positive relationship existed between the infected cases and financial markets in the USA and China over the analysis period. The results obtained from the study of Öztürk et al., (2020), who empirically examined the extent to which financial markets were affected by the pandemic, indicated that the sectoral indexes were more affected by the number of infected cases in Turkey rather than the number of infected cases in Europe and the World. It was determined that the negative economic impacts of the COVID-19 pandemic were mostly seen in the industries involving machinery and metal products. It was also observed that banking, insurance, and sports sectors followed those industries. Liu et al. (2020) examined the short-term impacts of the COVID-19 pandemic on 21 leading stock market indexes in 
Ergin Ünal, A., Yetiz, F. \& Süsay, A. (2022). The Impact of COVID-19 on Industrial, Banking and Tourism Indexes. Fiscaoeconomia, 6(1), 279-292. Doi: 10.25295/fsecon.1028730.

countries such as Korea, Japan, the USA, Germany, Singapore, the UK, and Italy. According to the findings obtained from the study, it was concluded that the stock markets plunged rapidly following the COVID-19 pandemic. Verma and Sinha (2020) investigated the impact of COVID19 cases on the Indian stock markets, especially the NSE. The impacts of COVID-19 on the NSE Nifty stock exchange over the period between May 16, 2019, and 13 May 13, 2020, were analyzed via the GARCH model. The analysis results revealed that the increase in the number of infected cases in India did not affect the average return of the NSE Nifty stock index, but increased the conditional variance.

\section{1. Literature Review Regarding the Impacts of COVID-19 on the Tourism Industry}

Tourism is one of the sensitive sectors affected by the pandemic process. Upon examining the literature, it is determined that the risks, uncertainty, and fear generated by COVID-19 have caused certain changes in the touristic consumption behaviors and the sector in Turkey, and predictions about the future have been made within the scope of the research study of Aydın and Doğan (2020). Acar (2020) examined the impacts of the COVID-19 pandemic on tourism both in the current and future periods. As a result of the study findings, the impressions were that the impacts of the new coronavirus would have been felt in the countries' economies for a long time and the tourism sector would have been affected by the situation. Gümüş and Haclevliyagil (2020) investigated the interaction between COVID-19 pandemic and tourism, transportation sectors and stock market indexes in Turkey via the ARDL Bounds Test approach. Findings obtained from the analysis indicated that no significant relationship existed between the number of cases of the pandemic and the indexes.

Özcan (2020) utilized the quarterly data obtained over the period between 2019:03-2020:09 for the efficiency of enterprises operating in the BIST tourism and transportation sectors, and their business performance was measured with the help of DEA and Tobin's q. According to the obtained results, it was concluded that it was not possible to mention the adverse impact of the COVID-19 pandemic on business performance in terms of the DEA analysis and that the COVID-19 pandemic had an adverse impact on business activities in both the transportation and tourism sectors according to Tobin's q ratio.

Bakar and Rosbi (2020) investigated the reflections of the pandemic on the tourism sector in countries around the world which were affected by COVID-19. In the study, supply and demand curves were used to determine the changes in the tourism sector. The study stated that COVID-19 caused panic for the public, which caused a decrease in demand for tourism services. Ghosh (2020) investigated the extent to which the quarantine economy related to COVID-19 negatively affected the Chinese market, which is an important customer of tourism in Australia. The nonlinear autoregressive distributed lag model was employed to comprehend the asymmetric relationship between tourism and uncertainty in the study examining the Chinese tourists who arrived in Australia over the period between 1996:Q1 - 2020:Q1. As a result of the research study, it was concluded that a 1 percent increase in uncertainty caused a 10 percent decrease in tourist arrivals, whereas a 1 percent decrease in uncertainty led to a 0.22 percent increase in tourist arrivals. Karim et al. (2020) conceptually investigated the impacts of the COVID-19 outbreak on the Malaysian tourism sector. Within the scope of the study, an inverse relationship was determined between the tourism sector and the pandemic. 
Ergin Ünal, A., Yetiz, F. \& Süsay, A. (2022). The Impact of COVID-19 on Industrial, Banking and Tourism Indexes. Fiscaoeconomia, 6(1), 279-292. Doi: 10.25295/fsecon.1028730.

\section{Data and Methology}

The data utilized in the study covers the period between 03.11.2020 - 04.22.2021. Upon determining the data range of the variables in the study, 03.11.2020, the date when the first infected case was seen in Turkey, is taken into consideration as a starting point. The daily closing prices of the variables are utilized and since the stock market is closed on weekends and public holidays, the data of all variables are obtained according to the dates on which the stock market has been open. A total of the 282-day dataset was utilized in the study. Since the Ministry of Health announced the number of confirmed daily infected cases as of 11.25.2020, the websites of both the World Health Organization (WHO) and the Ministry of Health were utilized in obtaining data on the number of confirmed daily infected cases. The logarithms of the variables used in the study were taken.

Table 1: Description the Variables

\begin{tabular}{|c|c|c|}
\hline VARIABLES & ACRONYM & DATA SOURCES \\
\hline $\begin{array}{c}\text { NUMBER OF CONFIRMED DAILY INFECTED } \\
\text { CASES }\end{array}$ & CASE & WHO- Ministry of Health \\
\hline BIST 1OO INDEX & XU100 & INVESTING \\
\hline BIST BANKING INDEX & XBANK & INVESTING \\
\hline BIST INDUSTRIAL INDEX & XINDR & INVESTING \\
\hline BIST TOURISM INDEX & XTRSM & INVESTING \\
\hline
\end{tabular}

In order to accurately measure the causality among the variables and to prevent the spurious regression relationship, it is necessary to test the stationarity of the variables by performing the unit root test. The Augmented Dickey-Fuller (ADF) unit root test (1981), which is frequently being used in the literature, is performed in the study. The Granger (1969) causality test requires that the series included in the model be rendered stationary. The causality test developed by Toda Yamamoto (1995) eliminates this requirement and prevents the loss of information caused by taking the difference of the series. Thus, much sounder results with more information are yielded. For the Toda-Yamamoto causality analysis, it is necessary to establish the VAR model, to determine the appropriate lag length $(k)$, as well as the highest order of integration $\left(d_{\max }\right)$ of the variables. The Toda-Yamamoto (1995) VAR model is defined as follows (Dritsaki, 2017:123).

$$
\begin{gathered}
Y_{t}=\mu_{0}+\left(\sum_{i=1}^{k} \alpha_{1 t} y_{t-i}+\sum_{i=k+1}^{d_{\max }} \alpha_{2 t} y_{t-i}\right)+\left(\sum_{i=1}^{k} \beta_{1 t} x_{t-i}+\sum_{i=k+1}^{d_{\max }} \beta_{2 t} x_{t-i}\right) \\
X_{t}=\emptyset_{0}+\left(\sum_{i=1}^{k} \gamma_{1 t} x_{t-i}+\sum_{i=k+1}^{d_{\max }} \gamma_{2 t} x_{t-i}\right)+\left(\sum_{i=1}^{k} \delta_{1 t} y_{t-i}+\sum_{i=k+1}^{d_{\max }} \delta_{2 t} y_{t-i}\right)
\end{gathered}
$$

In the equations, " $k$ " denotes the optimal lag length, and $d_{\max }$ indicates the maximum order of integration. In the Toda Yamamoto causality test, the null and alternative hypotheses are established as follows:

$\mathrm{H}_{0}$ : The independent variable does not Granger cause the dependent variable. 
Ergin Ünal, A., Yetiz, F. \& Süsay, A. (2022). The Impact of COVID-19 on Industrial, Banking and Tourism Indexes. Fiscaoeconomia, 6(1), 279-292. Doi: 10.25295/fsecon.1028730.

$\mathrm{H}_{1}$ : The independent variable Granger causes the dependent variable.

\section{Findings}

In the study, firstly, the stationarity test is performed to determine the maximum order of integration $\left(d_{\max }\right)$ of the variables.

Table 2: Unit Root Test Results

\begin{tabular}{|c|c|c|c|c|}
\hline \multirow{2}{*}{} & \multirow{2}{*}{ Variables } & \multicolumn{3}{|c|}{ ADF } \\
\cline { 2 - 5 } & & T Statistic & Probability & Results \\
\hline \multirow{4}{*}{$I(0)$} & XU100 & 0.996668 & 0.9159 & Non-stationary \\
\cline { 2 - 5 } & XBANK & -0.635795 & 0.4412 & Non-stationary \\
\cline { 2 - 5 } & XINDR & 2.433843 & 0.9966 & Non-stationary \\
\cline { 2 - 5 } & XTRSM & 2.044316 & 0.9905 & Non-stationary \\
\cline { 2 - 5 } & CASE & -6.906092 & $0.0000^{*}$ & Stationary \\
\hline \multirow{4}{*}{ I(1) } & XU100 & -18.03597 & $0.0000^{*}$ & Stationary \\
\cline { 2 - 5 } & XBANK & -17.12154 & $0.0000^{*}$ & Stationary \\
\cline { 2 - 5 } & XINDR & -17.48920 & $0.0000^{*}$ & Stationary \\
\cline { 2 - 5 } & XTRSM & -15.86053 & $0.0000^{*}$ & Stationary \\
\cline { 2 - 5 } & CASE & - & - & \\
\hline
\end{tabular}

$*, * *$ and $* * *$ values indicate the stationarity of the series at $1 \%, 5 \%$, and $10 \%$ significance levels, respectively. The optimal lag length is determined for the ADF according to the Schwarz method.

In the stationarity test, firstly, the deterministic components of the variables and their critical values are compared. The critical values in deterministic components are 2.38 in both models with intercept and with the trend, and 2.16 in the model with intercept. In the ADF unit root test, the XU100, XBANK, XINDR, and XTRSM variables are determined not to contain a deterministic component and the null hypothesis is rejected upon taking the first differences. The CASE variable is stationary at the level in both models with intercept and trend. According to the unit root test results, the maximum order of integration $\left(d_{\max }\right)$ of the variables is found to be " 1 ".

Once the maximum order of integration of the variables is determined, it is necessary to determine the lag lengths. In the study, the most appropriate lag length is determined as " 1 " according to the entire information criteria, except for the LR test statistic.

Table 3: Determining the Lag Length

\begin{tabular}{|c|c|c|c|l|l|l|}
\hline Lag & LogL & LR & FPE & AIC & SC & HQ \\
\hline 0 & 1017.776 & NA & $3.49 \mathrm{e}-10$ & -7.586339 & -7.519163 & -7.559355 \\
\hline 1 & 3387.519 & 4632.981 & $8.23 \mathrm{e}-18^{*}$ & $-25.14996^{*}$ & $-24.74690^{*}$ & $-24.98805^{*}$ \\
\hline 2 & 3410.494 & $44.05727^{*}$ & $8.35 \mathrm{e}-18$ & -25.13479 & -24.39584 & -24.83796 \\
\hline 3 & 3419.536 & 16.99980 & $9.42 \mathrm{e}-18$ & -25.01525 & -23.94042 & -24.58350 \\
\hline 4 & 3431.114 & 21.33416 & $1.04 \mathrm{e}-17$ & -24.91471 & -23.50400 & -24.34804 \\
\hline 5 & 3445.662 & 26.26214 & $1.13 \mathrm{e}-17$ & -24.83642 & -23.08982 & -24.13482 \\
\hline 6 & 3465.405 & 34.90184 & $1.18 \mathrm{e}-17$ & -24.79704 & -22.71455 & -23.96052 \\
\hline 7 & 3479.098 & 23.69463 & $1.28 \mathrm{e}-17$ & -24.71235 & -22.29398 & -23.74090 \\
\hline 8 & 3493.718 & 24.74847 & $1.39 \mathrm{e}-17$ & -24.63459 & -21.88033 & -23.52822 \\
\hline
\end{tabular}

After determining the optimal lag length $(k)$ and maximum order of integration $\left(d_{\text {max }}\right)$, the Toda-Yamamoto causality test is performed. Test results are presented in Table 4. 
Ergin Ünal, A., Yetiz, F. \& Süsay, A. (2022). The Impact of COVID-19 on Industrial, Banking and Tourism Indexes. Fiscaoeconomia, 6(1), 279-292. Doi: 10.25295/fsecon.1028730.

Table 4: Toda-Yamamoto Test Results

\begin{tabular}{|c|c|c|c|c|c|}
\hline $\begin{array}{l}\text { Dependent } \\
\text { Variables }\end{array}$ & $\begin{array}{c}\text { Independent } \\
\text { Variables }\end{array}$ & $k+d_{\max }$ & $\begin{array}{l}\text { Chi-square } \\
\text { Test Statistic }\end{array}$ & Probability & Causality \\
\hline XU100 & \multirow{4}{*}{ CASE } & $1+1$ & 10.73569 & $0.0011^{*}$ & CASE $\rightarrow$ XU100 \\
\hline XBANK & & $1+1$ & 3.212170 & $0.0731 * * *$ & CASE $\rightarrow$ XBANK \\
\hline XINDR & & $1+1$ & 11.07923 & $0.0009 *$ & CASE $\rightarrow$ XINDR \\
\hline XTRSM & & $1+1$ & 4.811481 & $0.0283^{* *}$ & CASE $\rightarrow$ XTRSM \\
\hline
\end{tabular}

$*, * *, * * *$ denote significance at the $1 \%, 5 \%$ and $10 \%$ level, respectively.

In the Toda-Yamamoto causality test, it is aimed to determine the impact of the number of daily infected cases on the indexes, so the CASE variable is included in the analysis as an independent variable. According to the obtained results, a unilateral causality is detected running from the CASE variable to the XU100, XBANK, XINDR, and XTRSM variables.

\section{Conclusion}

Many sectors, which involve various domains such as production, employment, trade, transportation, tourism, and finance, within the economies of countries struggling with the COVID-19 pandemic, which broke out in Wuhan, China, and spread to the world in a short time, have been positively or negatively affected in compliance with the growing needs. Within the scope of the fight against COVID-19, which has become a global problem and still continues to affect the whole world, all sectors aimed at maintaining their activities by taking new measures and conducting new practices to protect themselves. The extent to which sectors in the economy were affected throughout the pandemic process has been an intriguing research topic in the literature. Since the announcement of the first infected case in Turkey on March 11, 2020, to the present day, significant changes have begun to occur in many sectors. Therefore, the impacts of the COVID-19 pandemic on industrial, banking, and tourism sectors are examined based on the sectoral indexes. The relationships of the daily number of COVID-19 cases with the BIST 100, BIST Industrial, BIST Banking, and BIST Tourism indexes are investigated over the period between March 11, 2020 - April 22, 2021. The TodaYamamoto Causality test is performed for the study, in which the impacts of the COVID-19 pandemic on the industrial, banking, and tourism sectors are examined in terms of indexes. According to the obtained results, a unilateral causal relationship is determined running from the number of confirmed daily infected cases to all stock market indexes under examination.

Throughout the pandemic, temporary results such as a slowdown in production in certain domains and a decrease in demand for manufactured goods have emerged, while production and demand have increased in some sectors. For instance, with products such as food, cosmetics, health/hygiene, and cleaning utensils, as well as the spread of remote online working, the demand for the sectors concerning the products such as smartphones, computers, etc. has increased along with the increase in internet usage. Upon evaluating the industrial production sector, it has been temporarily adversely affected in this process due to the reduction of production, lack of production, or problems in international transportation services in the countries where the enterprises that import some of the raw materials or semifinished products used in production and maintain production in this process. For these reasons, there has been a decrease in some of the industrial production during the first wave of the pandemic. Nevertheless, along with the policy measures implemented to mitigate the 
Ergin Ünal, A., Yetiz, F. \& Süsay, A. (2022). The Impact of COVID-19 on Industrial, Banking and Tourism Indexes. Fiscaoeconomia, 6(1), 279-292. Doi: 10.25295/fsecon.1028730.

decline in production and employment, industrial production has entered the recovery process. Along with the changing customer behavior, banking activities have also begun to change. This situation has brought forth new practices in the banking sector. The banking sector, which quickly adapted to the pandemic process with its financial and technological equipment, has provided support packages with various loans and products to both the real sector and individual customers in order to reduce the adverse impacts of the pandemic on the economy. Credit support packages offered by banks are within the scope of solution proposals with appropriate limits, prices, and grace period applications. Banks have also supported companies whose cash flows have deteriorated during the pandemic, with the implementation of postponing and restructuring loans, interest, and principal \& interest payments. Furthermore, in order to reduce the rate of transmission of the COVID-19 pandemic, the banking sector has expanded the use of digital banking products/services to minimize human contact. Upon evaluating the reflections of the pandemic on the tourism sector, domestic and international travel restrictions in the early days of the COVID-19 pandemic caused a decrease in employment and tourism revenues. Along with the postponement and cancellation of reservation plans in the tourism sector, lodging companies, tour operators, and travel agencies were also temporarily adversely affected by such a recession. Nonetheless, it has been observed that the adverse impacts of the pandemic on the tourism sector have decreased within the scope of the tourism policies implemented during the normalization process. Particularly, it can be claimed that the continuation of the activities of tourism enterprises along with the necessary hygiene infrastructure, the increase in social distance tours, isolated holidays, the financial aid of the state, the postponement of taxes, and the credit supports have a positive impact on the activities of the tourism sector.

As in the countries where the pandemic has been experienced, it began to implement expansionary monetary and fiscal policies and took the necessary economic measures in order to prevent the spread of the pandemic in a short time in Turkey. In this ongoing process, in order to reduce the adverse impact on the production, banking, and tourism sectors, like every sector that has been affected by the COVID-19 pandemic at different levels, developments in Turkey are evaluated instantly and solutions are maintained, policies that would protect the sectors are concentrated on, and studies in this regard are sustained. It is thought that the study would be a guide for future similar research studies in terms of both the employed methodology and the obtained results, and would contribute to the literature in terms of the evaluated sectors.

\section{References}

Acar Y. (2020). Yeni Koronavirüs (COVID-19) Salgını ve Turizm Faaliyetlerine Etkisi. Güncel Turizm Araştırmaları Dergisi, 4(1), 7-21.

Adıgüzel, M. (2020). COVID-19 Pandemisinin Türkiye Ekonomisine Etkilerinin Makroekonomik Analizi. İstanbul Ticaret Üniversitesi Sosyal Bilimler Dergisi, Bahar (Covid19-Özel Ek), 191-221.

Amankwah-Amoah, J., Khan, Z., \& Wood, G. (2021). COVID-19 and Business Failures: The Paradoxes of Experience, Scale and Scope for Theory and Practice. European Management Journal, 39(2), 179-184. 
Ergin Ünal, A., Yetiz, F. \& Süsay, A. (2022). The Impact of COVID-19 on Industrial, Banking and Tourism Indexes. Fiscaoeconomia, 6(1), 279-292. Doi: 10.25295/fsecon.1028730.

Amit, S. A. J. I. D. (2020). Coronavirus and the Bangladesh Economy: Navigating the Black Swan Event of 2020. Dhaka Tribune.

Antipova, T. (2020). Coronavirus Pandemic as Black Swan Event. In International Conference on Integrated Science (pp. 356-366). Springer, Cham.

Arabacı, H. \& Yücel, D. (2020). COVID-19 Pandemisinin Türk Bankacılık Sektörü Üzerine Etkisi. Social Sciences Research Journal, 9(3), 196-208.

Aydın, B. \& Doğan, M. (2020). Yeni Koronavirüs (COVID-19) Pandemisinin Turistik Tüketici Davranışları ve Türkiye Turizmi Üzerindeki Etkilerinin Değerlendirilmesi. Pazarlama Teorisi ve Uygulamaları Dergisi, 6(1), 93-115.

Bakar, N. A. \& Rosbi, S. (2020). Effect of Coronavirus Disease (COVID-19) to Tourism Industry. International Journal of Advanced Engineering Research and Science, 7(4), 189-193.

Baker, S. R., Bloom, N., Davis, S. J. \& Terry, S. J. (2020). COVID-Induced Economic Uncertainty (No. w26983). National Bureau of Economic Research.

Bekçi, ì., Köse, E. \& Aksoy, E. (2020). COVID-19'un Türkiye'de Bankalar Üzerindeki Ekonomik Etkisine Dair Bir Tahmin. Ekonomi Politika ve Finans Araştırmaları Dergisi, COVID-19, 185-205.

Beybur, M. \& Çetinkaya, M. (2020). COVID-19 Pandemisinin Türkiye'de Dijital Bankacılık Ürün ve Hizmetlerinin Kullanımı Üzerindeki Etkisi. Uluslararası Batı Karadeniz Sosyal ve Beşeri Bilimler Dergisi, 4(2), 148-163.

Cinel, E. (2020). COVID-19'un Küresel Makroekonomik Etkileri ve Beklentiler, Politik Ekonomik Kuram, 4(1), 124-140.

Dickey, D. A. \& Fuller, W. A. (1981). Likelihood Ration Statistics for Autoregressive Time Series with a Unit Root. Econometrica, 49(4), 1057-1072.

Dritsaki, C. (2017). Toda-Yamamoto Causality Test between Inflation and Nominal Interest Rates: Evidence from Three Countries of Europe. International Journal of Economics and Financial Issues, 7(7), 120-129.

Dündar, N. (2020). Küresel Salgınların Makroekonomik Etkileri Üzerine Bir Araştırma. Journal of Social and Humanities Sciences Research, 7(52), 837-852.

Ghosh, S. (2020). Asymmetric Impact of COVID-19 Induced Uncertainty on Inbound Chinese Tourists in Australia: Insights from Nonlinear ARDL model. Quantitative Finance and Economics, 4(2), 343.

Granger, C. W. J. (1969). Investigating Causal Relations by Econometric Models and Cross Spectral Methods. Econometrica, 37(3), 424-438.

Greenwald, D. L., Krainer, J. \& Paul, P. (2020). The Credit Line Channel. Federal Reserve Bank of San Francisco Working Paper, No. 2020-26.

Gümüş, A. \& Hacıevliyagil, N. (2020). COVID-19 Salgın Hastalığının Borsaya Etkisi: Turizm ve Ulaştırma Endeksleri Üzerine bir Uygulama. Akademik Yaklaşımlar Dergisi, 11(1), 7697. 
Ergin Ünal, A., Yetiz, F. \& Süsay, A. (2022). The Impact of COVID-19 on Industrial, Banking and Tourism Indexes. Fiscaoeconomia, 6(1), 279-292. Doi: 10.25295/fsecon.1028730.

Julius, E., Nuugulu, S.,ve Julius, L. H. (2020). Estimating the Economic Impact of COVID-19: A Case Study of Namibia. Munich Personal RePEc Archive (MPRA Paper No 99641), 1-21.

Karabag, S. F. (2020). An Unprecedented Global Crisis! The Global, Regional, National, Political, Economic and Commercial Impact of the Coronavirus Pandemic. Journal of Applied Economics and Business Research, 10(1), 1-6.

Karim, W., Haque, A., Anis, Z., \& Ulfy, M. A. (2020). The Movement Control Order (MCO) for COVID-19 Crisis and its Impact on Tourism and Hospitality Sector in Malaysia. International Tourism and Hopitality Journal, 3(2), 1-7.

Kayakuş, M. \& Çevik, K. K. (2020). Estimation the Number of Visitor of E-Commerce Website by Artificial Neural Networks During COVID-19 in Turkey. Turkish Studies, 15(4), 615631.

Kılıç, Y. (2020). Borsa İstanbul'da COVID-19 (Koronavirüs) Etkisi. JOEEP: Journal of Emerging Economies and Policy, 5(1), 66-77.

Koyuncu, T. \& Meçik, O. (2020). COVID-19 Pandemisinin Türkiye'de Ekonomik Büyümeye Sektör-Spesifik Etkileri: Var Analizi. Yönetim ve Ekonomi Araştırmaları Dergisi, 18(4), 112-131.

Liu, H., Manzoor, A., Wang, C., Zhang, L., \& Manzoor, Z. (2020). The COVID-19 Outbreak and Affected Countries Stock Markets Response. International Journal of Environmental Research and Public Health, 17(8).

Ludvigson, S. C., Ma, S., \& Ng, S. (2020). Covid19 and the Macroeconomic Effects of Costly Disasters (No. w26987). National Bureau of Economic Research.

Matos, P. R., Costa, A. \& Silva, C. D. (2021). On the Risk-Based Contagion of G7 Banking System and the COViD-19 Pandemic. (March 15, 2021). Available at SSRN: https://ssrn.com/abstract=3805120 or http://dx.doi.org/10.2139/ssrn.380512 $\underline{0}$

Morales, L., \& Andreosso-O'Callaghan, B. (2020). Covid19: Global Stock Markets "Black Swan". Çevrimiçi, https://ulir.ul.ie/handle/10344/8728, Erişim Tarihi: 24.05.2021.

Ngwakwe, C. C. (2020). Effect of COVID-19 Pandemic on Global Stock Market Values: A Differential Analysis. Acta Universitatis Danubius. Economica, 16(2), 255-269.

Özcan, M. (2021). COViD 19 Pandemisinin Turizm ve Ulaştırma İşletmelerinin Finansal Performansına Etkisi. OPUS Uluslararası Toplum Araştırmaları Dergisi, Pandemi Özel Sayısı, 3547-3572.

Öztürk, Ö., Şişman, M.Y., Uslu, H., \& Çıtak, F. (2020). KOVID-19 Pandemisinin Türkiye Hisse Senedi Piyasasına Etkileri: Sektörel Bir Analiz. Hitit Üniversitesi Sosyal Bilimler Enstitüsü Dergisi, 13(1), 56-68.

Ramelli, S. \& Wagner, A. (2020). What the Stock Market Tells Us About the Consequences of COViD-19. In Baldwin, R. and Weder di Mauro, B. (Eds.), Mitigating the COVID Economic Crisis: Act Fast and Do Whatever, (63-71). London: CERP Press. Retrieved from http://www.itsr.ir/Content/upload/O79CBCOVIDEconomicCrisis.pdf\#page=70. 
Ergin Ünal, A., Yetiz, F. \& Süsay, A. (2022). The Impact of COVID-19 on Industrial, Banking and Tourism Indexes. Fiscaoeconomia, 6(1), 279-292. Doi: 10.25295/fsecon.1028730.

Sansa, N. U. (2020). The Impact of the COVID-19 on the Financial Markets: Evidence from China and USA. Electronic Research Journal of Social Sciences and Humanities, 2(11).

Soylu, Ö. B. (2020). Türkiye Ekonomisinde COVID-19'un Sektörel Etkileri. Avrasya Sosyal ve Ekonomi Araştırmaları Dergisi, 7(5), 169-185.

Şenol, Z. (2020). COVID-19 Krizi ve Finansal Piyasalar. Para ve Finans, 75-124.

Toda, H. Y., \& Yamamoto, T. (1995). Statistical Inference in Vector Autoregressions with Possibly Integrated Process. Journal of Econometrics, 66, 225-250.

Türkiye Seyahat Acentaları Birliği (TÜRSAB). (2020). COVID-19 Sürecinde Türkiye ve Dünya Turizmi

Değerlendirmesi.

https://www.tursab.org.tr/assets/assets/uploads/arastirmalar/COVID-19-surecindeturkiye-ve-dunya-turizmi.pdf (erişim Tarihi: 28.05.2021).

Verma, D. \& Sinha, P. K. (2020). Has COVID-19 Infected Indian Stock Market Volatility? Evidence from NSE. $\operatorname{AAYAM(10),~25-35.~}$

Wojcik, D. \& Ioannou, S. (2020). COVID-19 and Finance: Market Developments so far and Potential Impacts on the Financial Sector and Centres. https://onlinelibrary.wiley.com/doi/full/10.1111/tesg.12434.

Yan, B., Stuart, L., Tu, A., \& Zhang, T. (2020). Analysis of the Effect of COViD-19 on the Stock Market and Investing Strategies. Available at SSRN 3563380.

Yarovaya, L., Matkovskyy, R., \& Jalan, A. (2020). The Effects of a 'Black Swan' Event (COVID19) on Herding Behavior in Cryptocurrency Markets: Evidence from Cryptocurrency USD, EUR, JPY, and KRW Markets. EUR, JPY, and KRW Markets (April 27, 2020).

Ethics Statement: The authors declare that ethical rules are followed in all preparation processes of this study. In case of detection of a contrary situation, Fiscaoeconomia has no responsibility and all responsibility belongs to the authors of the study.

Author Contributions: Ayşe ERGIN ÜNAL and Filiz YETiZ contributed to the study in Introduction, Conclusion, Theoretical Framework and Empirical Literature sections and data collection stages. Aynur SÜSAY and Ayşe ERGIN ÜNAL contributed to the study in the Introduction, Data Set, Econometric Methodology and Results sections, in the data collection and analysis stages. the authors contributed equally well.

Conflict of Interest: There is no conflict of interest between the authors. 